\title{
Art librarians' professional paths: a careers survey with implications for prospective librarians
}

\author{
Eamon C. Tewell
}

I

s there such thing as a 'typical' career path for art librarians? This article presents the results of a survey of art librarians' motivations for selecting the profession, and also their educational backgrounds, current employment and professional experiences, and presents advice for graduate students and prospective librarians. A questionnaire was sent to six email discussion groups related to art librarianship, from which 280 responses were received from across the world. The results indicate that art librarians typically work in academic settings, chose the field of art librarianship while already employed in libraries, have an educational background in the arts at the undergraduate and/or graduate level, and selected librarianship primarily because they were attracted to the duties and work settings of the job. This study includes advice from current librarians for graduate students seeking employment as art librarians in today's challenging job market.

Every professional has their own story of how they selected their field, ranging from serendipity to a methodically plotted career course. Art librarianship is no different. This article considers the essential questions behind choosing art librarianship as a career path: What are the typical educational backgrounds of art librarians? Where and in what capacity are they employed? At what point in their education/career development did they decide to pursue art librarianship? What lessons from current professionals in the field can prospective art librarians use to enhance their own career search?

Numerous studies have reported on the backgrounds of librarians in various settings and specialties, yet no publications to date have examined the career paths of art librarians, particularly with recommendations for Library \& Information Science (LIS) graduate students and new librarians entering the profession. Seasoned professionals can offer critical career path recommendations to prospective art librarians, and this study shares those recommendations with students and job seekers facing an exceptionally challenging employment market and economic climate. Reviewing the preparation and actual job experiences of current practitioners in art librarianship allows us all to benefit from a deeper knowledge of the current state of the profession.

To achieve this, a survey was developed to gather data on professional art librarians' education, current and previous positions, career goals, and advice for prospective art librarians. The results of the survey were then analyzed and categorized to provide insight into the following questions:

- Was art librarianship a career goal for most professionals currently in the field?

- Why do individuals choose a career in art librarianship?

- What factors contributed to current professionals successfully obtaining a position as an art librarian?

\section{Literature review}

The broad subject of careers in librarianship has been addressed in many studies over the previous three decades. But while there is a body of literature regarding a range of settings and specialties in 
librarianship, no research to date has focused on the careers, background and employment of art librarians. In addition, few journal articles examine the library profession from an international perspective or provide advice for students and new professionals seeking to enter the field, which are two significant factors this study addresses. There are, however, many notable contributions to the literature.

In 1985, Barbara Dewey examined Library \& Information Science students' choice of librarianship as a career, concluding that the largest factor in selecting the LIS field was the influence of practising librarians in the field. ${ }^{1}$ Over the years research by a number of authors has investigated the motivation for students' choice of the profession combined with an emphasis on the need for recruitment of new professionals, as shown by Van House's 1988 analysis of students' career selection, ${ }^{2}$ a survey of both librarians of color and LIS students with advanced degrees in other fields conducted by Sun et al., ${ }^{3}$ and research conducted in 2006 and 2010 at the University of Alabama exploring the factors at work in LIS students' attraction to the profession. ${ }^{4,5}$

In the area of art librarianship, very few publications have considered the background or career paths of professionals. Most relevant to this study is Bierbaum, who surveyed 121 museum, arts and humanities librarians in 1988, and found that a majority came to museum librarianship from other specialties or professions. ${ }^{6}$ Ferrari addressed the topic of people with doctorates in art librarianship, surveying the ARLIS-L email discussion list and finding from the small sample of respondents having obtained a doctorate that they felt the degree enhanced their careers. ${ }^{7}$ In 1990 and 2004 ARLIS/NA undertook comprehensive surveys of members' salaries and institutional resources. These reports included data on personal respondents' education and job responsibilities. ${ }^{8,9}$ Most recently, the Visual Resources Association (VRA) conducted a survey to investigate the status of the profession at both individual and institutional levels. Findings include a large proportion of respondents employed in academic settings ( 83 per cent) and the fact that nearly 47 per cent of respondents were between the ages of 46 and $60 .^{10}$

While many articles survey the interests or backgrounds of library students and professionals, this present paper provides specific insight into the career goals and education of art librarians worldwide. In addition, it provides advice from these experienced professionals for the benefit of LIS students and graduates seeking to enter the unique field of art librarianship.

\section{Method}

The questionnaire was developed after a review of the existing library literature on career decisions and subject specialisms. The survey was pilot-tested by three art librarians and revised in line with their suggestions. A web-based survey was distributed internationally via six email discussion lists related to art librarianship, and consisted of 33 items, including three open-ended questions. These discussion lists, indicated below, were selected for their focus on arts librarianship and their frequent use as advice forums for practitioners in the field.

[arts-lib] Association of College \& Research Libraries, Arts Section (ACRL Arts)

[arlis-1] Art Libraries Society of North America (ARLIS/NA)

[carlis-l] ARLIS/NA Canada [arlis-norden] ARLIS in the Nordic countries [arlis-link] ARLIS/UK \& Ireland [ifla-art] International Federation of Library Associations, Art Library Section

The data were collected during April 2011 using Google Forms software and exported to an Excel spreadsheet for analysis.

\begin{tabular}{|lcc|}
\hline \multicolumn{3}{c|}{ Table 1. Respondents by age } \\
\hline Age & Frequency & Percentage \\
\hline $18-26$ & 6 & 2.1 \\
$27-35$ & 63 & 22.5 \\
$36-44$ & 61 & 21.8 \\
$45-53$ & 66 & 23.6 \\
$54-62$ & 69 & 24.6 \\
$63+$ & 15 & 5.4 \\
\hline Total & 280 & 100 \\
\hline
\end{tabular}

\section{Results}

\section{Demographics}

The survey yielded 280 valid responses from across the world. Data included respondents' age, gender and location. Females represented 84 per cent of the sample. Notably, in a field highly concerned with the graying of the profession, there was a relatively even distribution among age groups between 27 and 62 .

Table 1 shows the distribution of respondents by age.

As was to be expected, locations of respondents corresponded with the prevailing geographical domain of the email discussion groups the survey was sent to, with a majority of respondents in the United States (57 per cent) and the United Kingdom (18 per cent). Table 2 includes a complete list of respondents by their location. 


\begin{tabular}{|c|c|c|}
\hline \multicolumn{3}{|c|}{ Table 2. Respondents by location } \\
\hline Country & Frequency & Percentage \\
\hline United States & 159 & 56.8 \\
\hline United Kingdom & 51 & 18.2 \\
\hline Canada & 25 & 8.9 \\
\hline Denmark & 5 & 1.8 \\
\hline Iceland & 5 & 1.8 \\
\hline Australia & 4 & 1.4 \\
\hline Mexico & 3 & 1.1 \\
\hline Norway & 3 & 1.1 \\
\hline Sweden & 3 & 1.1 \\
\hline Finland & 2 & 0.7 \\
\hline Greece & 2 & 0.7 \\
\hline Ireland & 2 & 0.7 \\
\hline Israel & 2 & 0.7 \\
\hline South Africa & 2 & 0.7 \\
\hline Switzerland & 2 & 0.7 \\
\hline Belgium & 1 & 0.4 \\
\hline Brazil & 1 & 0.4 \\
\hline Germany & 1 & 0.4 \\
\hline India & 1 & 0.4 \\
\hline Italy & 1 & 0.4 \\
\hline Lebanon & 1 & 0.4 \\
\hline Portugal & 1 & 0.4 \\
\hline Scotland & 1 & 0.4 \\
\hline Spain & 1 & 0.4 \\
\hline Uruguay & 1 & 0.4 \\
\hline Total & 280 & 100 \\
\hline
\end{tabular}

\section{Current employment}

Respondents were asked, 'Which area best describes your job duties?' and allowed to select from Public Services (such as reference, instruction or access services), Technical Services (such as cataloging or serials), Digital Services (such as website management or image digitization), General (a combination of the above categories), Administrative or 'Other'. Thirty-four per cent felt their job duties most closely resembled a combination of Public Services, Technical Services, and/or Digital Services (that is, 'General') while 27 per cent selected Public Services as their primary job responsibility.

Administrative (16 per cent), 'Other' (13 per cent), Technical Services (8 per cent) and Digital Services (3 per cent) followed, suggesting that a majority of employment opportunities in art librarianship require a rounded background combining multiple skill sets.

Regarding place of work, a majority of respondents were employed in an academic setting (58 per cent). Museums were the next most likely location, followed by 'Other', Special, Public and Archives. Figure 1 displays the types of institutions in which respondents reported being employed.

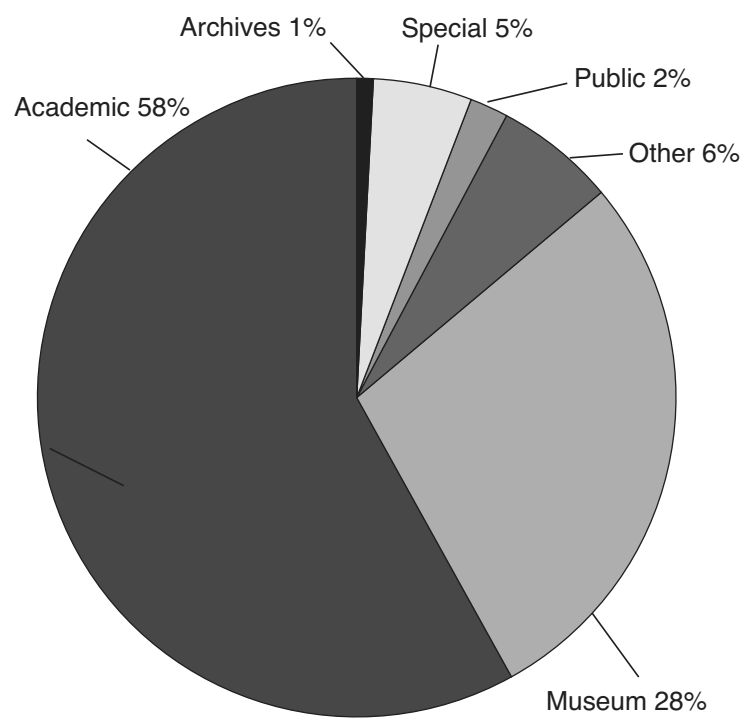

Figure 1. In which type of institution are you currently employed?

\section{Education}

While many respondents had educational backgrounds in art history and studio art, a significant number reported other undergraduate majors. Of the 280 respondents, 35 per cent had received a degree in Art History and 12 per cent in Art/Studio Art. The variety of disciplines recorded suggests that an undergraduate-level education in the arts may enhance one's success in obtaining a position as an art librarian, but is not necessarily required. When asked, 'Do you possess an ALAaccredited Master's degree in Library and Information Science or its equivalent?' 100 per cent of valid respondents answered in the affirmative. Fifty-seven per cent had obtained a second Master's degree or its equivalent, with the most frequent areas of study being Art History (52 per cent), Fine Arts (16 per cent), Architecture (11 per cent) and History (4 per cent).

\section{Career goals}

The factors influencing respondents to pursue librarianship as a career were wide-ranging, but clear themes were found in the results. Respondents, allowed to select multiple responses, ranked 'Compensation' and 'Recommendation from friend or co-worker' low (40 and 49 respondents, respectively) while 'Job functions' (179 respondents) and 'Work setting' (146 respondents) ranked at the top. Points frequently mentioned in the comments were an attraction to the variety of day-to-day work in the field, librarianship as an alternative to teaching fulltime, and the ability to use or be immersed in one's subject specialty. 


\section{Selecting the profession}

In order to better understand respondents' reasons for selecting the profession, they were asked the open-ended question, 'What factors (either positive or negative) have had the strongest influence on your career choice?' A significant number of librarians pointed to the ability to combine their passion for both art and public service, with others noting that their disillusion with a previous career choice had paved the way for a change to librarianship. Others enjoyed the stability of the job, with librarianship offering daytime work hours, a steady paycheck, and the ability to pursue outside interests, artistic or otherwise.

Overall, satisfaction with the field is high, with 79 per cent intending to continue their career in art libraries, 16 per cent undecided, and only 2 per cent not planning to continue in this field. When asked to explain their responses a general enthusiasm surfaced for the profession, with an undertone of caution regarding the field's limited job opportunities. High job satisfaction was tempered with salary concerns, including unease about the effect of low pay on saving for retirement. There were numerous mentions of working in the field until retirement, summed up by the succinct comment, 'Love my job. Next stop retirement.'

\section{Advice for prospective art librarians}

Two multiple-response and one open-ended question were designed to elicit information from respondents regarding their personal preparation for art librarianship. Respondents indicated that their 'Background in the arts' and 'Experience' were the most significant factors towards obtaining their first position in an art library. Interestingly, 20

professionals mentioned 'Luck' as a factor in obtaining a position in an art library. The responses are summarized in Figure 2.

Lastly, art librarians were asked how graduate students should best prepare themselves for today's job market. The respondents voiced a wide range of thoughts on the most important aspects of preparing oneself for securing employment. Several key themes were reflected in the responses. First and foremost, respondents advised gaining as much experience in the field as possible, and many listed library internships as a particularly fruitful avenue for obtaining practical on-the-job skills. The willingness to relocate to another part of the country was seen by some professionals as necessary for finding employment in a daunting economic environment, summed up in one librarian's advice to

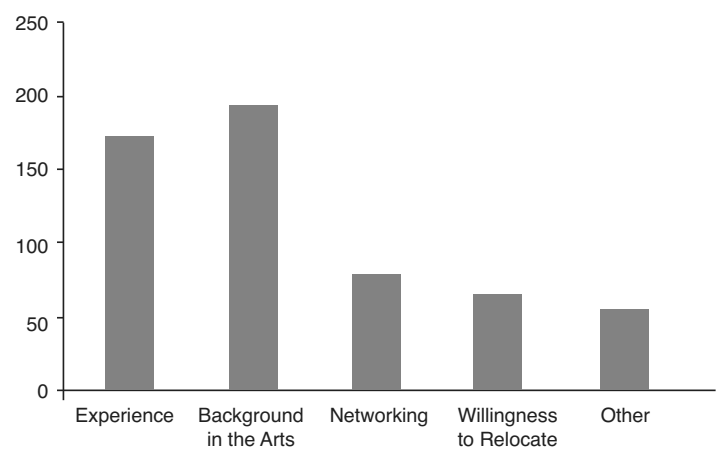

Figure 2. Which factors contributed most to obtaining your first position in an art library? (Check all that apply)

'be prepared to move for your first professional post once you've got that experience you stand a much better chance of getting jobs you really want'.

The importance of networking was also frequently mentioned. One respondent suggested networking both in person and online, advising graduate students to 'network continuously through local and national professional organizations as well as social sites such as LinkedIn and Facebook and also through personal/work relationships', while another pointed out that 'Networking might not secure you a job directly, but [it] will increase your confidence in the field'. The general impression left by many professionals was that those new to librarianship might need to settle for a less than perfect position and work their way towards opportunities better suited to their career goals. Other respondents acknowledged that in a difficult job market, a job outside of libraries requiring customer service or management skills is better than no job at all and can be a stepping stone towards library work.

Perhaps most significantly, respondents urged those new to the profession to manage their personal expectations about their career trajectory. While a small number of art librarians recommended graduate students not to pursue a specialty in art librarianship or a career in librarianship in general, a more widely-held view acknowledges that competition for positions is fierce, and one must put in considerable effort to make one's achievements stand out. As one respondent implored, 'Keep an open mind. Show willingness and enthusiasm. Don't give up!'

\section{Conclusion}

This study examines the career paths of art librarians and offers recommendations for LIS graduate students and librarians new to the field. The results show that the 'typical' art librarian is employed in an academic setting, has a background in the arts at 
undergraduate or graduate level, selected

librarianship because of an attraction to the job duties and work setting, and chose art librarianship while already employed in a library in some other capacity. Additionally, graduate students and those seeking a position in art libraries should prepare for the job market by gaining as much experience as possible, looking for and acting upon opportunities to talk and network with those in the field, and remaining flexible regarding initial job expectations.

More than half the survey respondents chose to pursue art librarianship while already employed in libraries. This suggests that while art librarianship is not frequently made a career goal by students in graduate school or college, individuals already in the workforce seek it after some consideration. Further, the fact that nearly every respondent selected 'Job functions' as a factor in their decision to pursue a career in libraries indicates that the intrinsic work of librarianship holds appeal for many. Overall, a sincere satisfaction with the profession was found, and only a handful of respondents mentioned unappealing aspects such as low compensation and few positions being available. A formal education in the arts appears to be de facto for many art librarians. While only half the respondents reported a bachelor's degree or its equivalent in the arts, 80 per cent of those who had obtained a master's degree had done so in art history, the fine arts, or architecture.

An interesting finding of this study, and one the author believes should be examined further, is the fairly even distribution of the ages of art library professionals. Does this represent an influx of younger librarians that will come to reflect a broader trend in the profession, or could this relatively even distribution between ages 27 and 62 be unique to art libraries? A sizeable body of library literature is devoted to discussing generational shifts in the workplace, and a larger-scale study in this area may be warranted based on these initial findings.

To determine the future of arts librarianship we as information professionals must know where the field currently stands. In order to locate opportunities for collaboration and meet user needs in new and unanticipated ways, we must be able to identify key characteristics of the profession and our collective experience. This includes recognizing commonalities among the profession's many individuals as well as person-specific reasons for selecting art librarianship as a career. The quality of advice provided to graduate students will play a significant role in helping to determine the future of art libraries as these new professionals choose to join the field, find their own career paths, contribute their voices, and continue to shape librarianship for years to come.

\section{References}

1. Barbara I. Dewey, 'Selection of librarianship as a career: implications for recruitment,' Journal of education for library and information science 26, no. 1 (1985): 16-24.

2. Nancy A. Van House, 'MLS students' choice of a library career,' Library and information science research 10 (1988): 161, 172.

3. Kim Kyung-Sun et al., 'Recruiting a diverse workforce for academic/research librarianship: career decisions of subject specialists and librarians of color,' College \& research libraries 68, no. 6 (2007): 533-552.

4. Allyson Ard et al., 'Why library and information science? Results of a career survey of MLIS students along with implications for reference librarians and recruitment,' Reference and user services quarterly 45, no. 3 (2006): 236-248.

5. Stephanie D. Taylor et al., 'A follow-up study of the factors shaping the career choices of library school students at the University of Alabama,' Reference \& user services quarterly 50, no. 1 (Fall 2010): 35-47.

6. Esther Green Bierbaum, 'Museum, arts, and humanities librarians: careers, professional development, and continuing education,' Journal of education for library \& information science 29, no. 2 (Fall 1988): 127-134.

7. Roberto C. Ferrari, 'To PhD, or not to PhD: a question for art librarians,' Art documentation 26, no. 1 (Spring 2007): 51-55.

8. Ann B. Abid and Henry A. Pisciotta, ARLIS/NA salary survey, 1990 (Tucson: Art Libraries Society of North America, 1991).

9. Kathrin Dodds and Heather Ball, comps., ARLIS/NA 2004 Art/Architecture librarians and visual resource professionals compensation survey (Art Libraries Society of North America, 2005), http://www.arlisna.org/pubs/onlinepubs/ compensation.pdf.

10. Visual Resources Association Ad Hoc Professional Status Survey Committee, '2007 professional status survey: 2008 final report,' VRA bulletin 36, no. 1 (Spring 2009): 60-107.

Eamon C. Tewell
Reference Librarian
Sarab Lawrence College
1 Mead Way
Bronxville, NY10708
USA
Email: etewell@sarablawrence.edu


Copyright of Art Libraries Journal is the property of ARLIS-UK \& Ireland and its content may not be copied or emailed to multiple sites or posted to a listserv without the copyright holder's express written permission.

However, users may print, download, or email articles for individual use. 